\title{
Iron Therapy and Refeeding in Experimentally Malnourished Rats
}

\author{
S. O. OLUSI(13) AND H. MCFARLANE \\ Department of Medical Biochemistry, Medical School, The University of Manchester, Manchester, England
}

\begin{abstract}
Summary
1. Rats suffering from protein-energy malnutrition were found to have low serum iron, low PCV, and low hemoglobin concentrations.

2. Oral iron supplement during the refeeding of these animals caused various types of infection, the severity of which was related to the dose of iron given.

3. A close association between high serum iron, low serum transferrin, and high incidence of bacterial infection was found.

4. A high protein diet without any oral iron supplement was found to raise the PCV and hemoglobin concentration to the same levels as a high protein diet containing $65 \mathrm{mg}$ iron/ $\mathrm{kg}$ body wt/day, although this dose of iron was sufficient to produce infection in the malnourished rats during refeeding.

\section{Speculation}

Iron supplementation during the treatment of children with protein-energy malnutrition may predispose to bacterial infection, the severity of which depends on the dose of iron given.
\end{abstract}

Although all are agreed that iron-deficiency anemia is a common problem in malnourished children, there is no agreement regarding the addition of iron to the diet during the treatment of these children. Segura et al. (12) suggested that malnourished infants should be given supplements of iron to combat iron-deficiency anemia.

On the other hand, McFarlane et al. (7) reported that some children with severe kwashiorkor developed overwhelming infections during treatment. This study is concerned with the effects of iron therapy during the refeeding of experimentally malnourished rats.

\section{MATERIALS}

ANIMALS

Seventy weanling male Sprague-Dawley rats were used.

\section{DIETS}

A high protein diet and a low protein diet (average grade baker's flour) were used. The low protein diet was fortified with vitamins by adding $10 \mathrm{~g}$ of a mixture of soluble vitamins (vitamin $\mathrm{D}$ fortification mixture in dextrose) to every $500 \mathrm{~g}$ baker's flour. The compositions of the two diets are shown in Tables 1 and 2.

\section{IRON PREPARATION AND DOSAGE}

Iron tablets were used. These were ground into powder. Ganote and Nahara (2) reported that large doses of ferrous sulfate were toxic in rats. Since the optimal iron requirements of rats are not known, it was decided to employ the following different dose schedules: $65,130,195$ and $200 \mathrm{mg} / \mathrm{kg}$ body wt/ day. Each rat was weighed and the calculated daily dose of iron powder required was added to its diet.

\section{OTHER MATERIALS}

Antisera to rat transferrin and C3 were obtained from Cappel Laboratories, Inc., USA, while anti-rat albumin and IgG were obtained from Miles Laboratories. Iron determination kits were obtained from Boehringer Corporation Ltd.

\section{METHODS}

Malnutrition was established in Sprague-Dawley rats by feeding them ad libitum for 42 days on average grade baker's flour which had been fortified with multivitamins.

The rats were placed in individual stainless steel cages and were allowed free access to distilled water. At the end of this period, the animals had developed some loss of hair and their mean body weight was $80.5 \pm 20.3 \mathrm{~g}$ compared with $320 \pm$ $60.5 \mathrm{~g}$ for those fed on a high protein mouse cube diet. Ten of these malnourished animals and 10 well fed controls had their eyes swabbed for bacteriologic investigations and were then killed. Blood was collected for $\mathrm{Hb}, \mathrm{PCV}$, and for serum albumin, transferrin, C3, and iron estimations. The remaining malnourished rats were divided into five groups, each consisting of 10 animals, and were refed with the high protein mouse cube diet as follows: group I, diet containing $65 \mathrm{mg}$ iron $/ \mathrm{kg}$ body wt/ day; group II, diet containing $130 \mathrm{mg}$ iron/kg body wt/day; group III, diet containing $195 \mathrm{mg}$ iron/kg body wt/day; group IV, diet containing $260 \mathrm{mg}$ iron/ $\mathrm{kg}$ body wt/day, group V, diet with no iron. Ten well fed control animals were each given the high protein diet containing $260 \mathrm{mg}$ iron/ $\mathrm{kg}$ body wt/day.

All of the animals were examined daily for evidence of infections. Thirty days after the commencement of oral iron supplement, the animals receiving 195 and $260 \mathrm{mg}$ iron/ $\mathrm{kg}$ body wt/day developed severe conjuctivitis and it was therefore decided to terminate the experiment. The animals from each group including the well fed controls were then weighed, had their eyes swabbed for bacteriologic investigations, and were killed. Blood was collected for $\mathrm{Hb}, \mathrm{PCV}$, and for serum albumin, transferrin, $\mathrm{C} 3$, and iron concentrations.

\section{COLLECTION OF SPECIMENS}

The animals were anesthetized with ether and exsanguinated by cannulating the abdominal aorta.

\section{BACTERIOLOGIC INVESTIGATIONS}

Individual animals were classified for severity of infection without knowledge of the iron dose or biochemical results. Eye swabs were used to inoculate blood agar plates (incubated aerobically and anaerobically), chocolate agar plates, and McConkey plates. Organisms were identified by the techniques described by Cowan and Steel (1).

\section{SERUM PROTEIN ESTIMATIONS}

The concentrations of albumin, transferrin, C3, and IgG were estimated in all the serum samples by the single radial immunodiffusion technique of Mancini et al. (5) using monospecific 
Table 1. Comparative composition of rat diets

\begin{tabular}{lcc}
\hline & Average grade baker's flour & Mouse cubes \\
\hline Protein $(\mathrm{g} / 00 \mathrm{~g})$ & $(n \times 5.7) 11.5$ & $(n \times 6.2) 20$ \\
Carbohydrate $(\mathrm{g} / 100 \mathrm{~g})$ & 74.0 & 68.0 \\
Fat $(\mathrm{g} / 100 \mathrm{~g})$ & 1.5 & 3.0 \\
Vitamin $\mathrm{B}$, thiamine $(\mathrm{mg} / 100 \mathrm{~g})$ & 0.24 & 1.05 \\
$\mathrm{~B}_{2}$, riboflavin $(\mathrm{mg} / 100 \mathrm{~g})$ & 0.4 & 1.50 \\
$\mathrm{~B}_{6}$, pyridoxine, etc. $(\mathrm{mg} / 100 \mathrm{~g})$ & 0.10 & Naturally occurring \\
$\mathrm{B}_{12}$, cobalamine $(\mathrm{mg} / 100 \mathrm{~g})$ & 0.0 & 0.34 \\
Niacin-nicotinic acid $(\mathrm{mg} / 100 \mathrm{~g})$ & 1.6 & Naturally occurring \\
Pantothinic acid & 1 & Naturally occurring \\
Biotin $(\mu \mathrm{g})$ & 0.5 & Naturally occurring \\
Folic acid $(\mu \mathrm{g})$ & 7.0 & Naturally occurring \\
Vitamin $\mathrm{A}(1 \mathrm{U} / 100 \mathrm{~g})$ & Added as stated & 39.28 \\
Vitamin $\mathrm{D}(1 \mathrm{U} / 100 \mathrm{~g})$ & & 90.2 \\
Vitamin $\mathrm{E}(1 \mathrm{U} / 100 \mathrm{~g})$ & & 0.12 \\
Vitamin $\mathrm{K}^{2}(\mathrm{mg} / 100 \mathrm{~g})$ & 1.65 & 0.05 \\
Iron $(\mathrm{mg} / 100 \mathrm{~g})$ & 300 & All the known trace metals were added \\
Calcium carbonate $(\mathrm{mg} / 100 \mathrm{~g})$ & 34.1 & in bulk quantity at a concentration of 5 \\
Magnesium $(\mathrm{mg} / 100 \mathrm{~g})$ & 0.17 & 1b/ton \\
Copper $(\mathrm{mg} / 100 \mathrm{~g})$ & 2.2 & \\
Sodium $(\mathrm{mg} / 100 \mathrm{~g})$ & 82.0 & \\
Potassium $(\mathrm{mg} / 100 \mathrm{~g})$ & 47.8 & \\
Chloride $(\mathrm{mg} / 100 \mathrm{~g})$ & &
\end{tabular}

${ }^{1}$ No estimations have been made.

${ }^{2}$ Known to be synthesized by the rat.

Table 2. Concentration of amino acids (grams) per $g$ nitrogen of various diets ${ }^{1}$

\begin{tabular}{cccc}
\hline Amino acids & Flour $70-75 \%$ ext & Meat & Fish \\
\hline Arg & 0.23 & 0.41 & 0.36 \\
Cys & 0.13 & 0.08 & 0.07 \\
Hist & 0.13 & 0.20 & 0.13 \\
Ileu & 0.24 & 0.32 & 0.32 \\
Leu & 0.43 & 0.49 & 0.47 \\
Lys & 0.13 & 0.51 & 0.56 \\
Met & 0.10 & 0.15 & 0.18 \\
Phe & 0.32 & 0.32 & 0.23 \\
Thr & 0.18 & 0.28 & 0.28 \\
Try & 0.06 & 0.08 & 0.06 \\
Tyr & 0.20 & 0.21 & 0.19 \\
Val & 0.29 & 0.33 & 0.33 \\
& & & \\
Ala & 0.17 & 0.39 & 0.38 \\
Asp & 0.26 & 0.57 & 0.59 \\
Glu & 2.10 & 0.96 & 0.88 \\
Gly & 0.21 & 0.28 & 0.38 \\
Pro & 0.72 & 0.27 & 0.37 \\
Ser & 0.30 & 0.26 & 0.33 \\
\hline
\end{tabular}

' Note the low content of lysine in the flour diet. The amino acid content of meat and fish are given as these are the chief protein in the mouse cubes. The horizontal space in the table divides the essential from the nonessential amino acids.

antisera. Results were expressed as percentages of the concentrations of these proteins in a pooled serum sample obtained from adult rats, because we could not obtain a standard rat serum containing known values of the above proteins.

\section{SERUM IRON ESTIMATIONS}

The concentration of iron in each serum sample was estimated using the Boehringer iron determination kit. The method involves the colorimetric estimation of iron at wavelength $546 \mathrm{~nm}$, care being taken to avoid using hemolyzed serum samples. Values were expressed in micrograms per $100 \mathrm{ml}$.

\section{RESULTS}

Table 3 shows the clinical, hematologic, and biochemical information on the control and malnourished rats before the commencement of oral iron therapy. Table 3 shows that mean body weight, $\mathrm{Hb}, \mathrm{PCV}$, and serum iron were significantly lower $(P<0.01)$ in malnourished rats than in controls, suggesting that malnutrition causes anemia associated with a low serum iron. This table also shows that the serum concentrations of transferrin and $\mathrm{C} 3$ were significantly lower $(P<0.01)$ in malnourished than in control animals.

\section{CLINICAL OBSERVATIONS AFTER IRON SUPPLEMENTATION}

All the malnourished rats that were given oral iron during refeeding with a high protein diet developed various types of infection, the severity of which was directly proportional to the dose of iron given. Thus all the malnourished rats that were given $260 \mathrm{mg}$ iron/ $\mathrm{kg}$ body wt/day during refeeding developed bilateral conjuctivitis (Fig. $1 A$ ), infections of the nostrils, tails, and limbs. On the contrary, of the malnourished rats that received no oral iron supplement during refeeding, none developed any clinical evidence of infection (Fig. $1 B$ ). The observation was also made that all the malnourished rats on iron supplement gained weight during refeeding, although the gain in weight was significantly reduced in those animals that had severe infections as a result of high iron intake. Malnourished animals that were not given any oral iron supplement during refeeding gained weight just as readily as those that were given $65 \mathrm{mg}$ iron $/ \mathrm{kg}$ body wt/day. Table 4 contains a summary of these clinical observations.

\section{HEMATOLOGIC DATA (TABLE 4)}

The $\mathrm{Hb}$ and PCV rose to almost the same levels in malnourished rats that had no iron during refeeding and those that had $65 \mathrm{mg}$ iron/ $\mathrm{kg}$ body wt/day, suggesting that although this amount of iron was capable of producing infection, it did not alter significantly the hematologic status of the animal. The $\mathrm{Hb}$ and PCV fell in those animals that had infections, suggesting that although iron was being absorbed, it was not being utilized for hemoglobin synthesis. 
Table 3. Clinical, hematologic, and biochemical information on malnourished and control rats before beginning of oral iron supplementation ${ }^{\mathrm{i}}$

\begin{tabular}{|c|c|c|c|c|c|c|c|c|c|c|}
\hline \multirow{2}{*}{$\begin{array}{l}\text { Animal } \\
\text { group }\end{array}$} & \multirow{2}{*}{$\begin{array}{c}\text { No. of } \\
\text { animals }\end{array}$} & \multirow{2}{*}{$\begin{array}{l}\text { Mean body } \\
\text { wt }( \pm \text { SD }), g\end{array}$} & \multirow{2}{*}{$\begin{array}{l}\text { Clinical } \\
\text { infection }\end{array}$} & \multirow[b]{2}{*}{ PCV, \% } & \multirow[b]{2}{*}{$\mathrm{Hb}, \mathrm{g} / 100 \mathrm{ml}$} & \multirow{2}{*}{$\begin{array}{l}\text { Serum iron, } \\
\mu \mathrm{g} / 100 \mathrm{ml}\end{array}$} & \multicolumn{4}{|c|}{ Mean serum conc expressed as $\%$ of standard } \\
\hline & & & & & & & Albumin & Transferrin & $\mathrm{C} 3$ & $\operatorname{IgG}$ \\
\hline Control & 10 & $320 \pm 60.5$ & Absent & $43 \pm 5$ & $14.6 \pm 2.6$ & $165 \pm 10$ & $98.6 \pm 10.3$ & $98 \pm 11.8$ & $97.5 \pm 15$ & $99.7 \pm 10$ \\
\hline $\begin{array}{l}\text { Malnour- } \\
\text { ished }\end{array}$ & 10 & $80.5 \pm 20.3$ & Absent & $30.2 \pm 3.5$ & $8.8 \pm 1.3$ & $95.8 \pm 13.6$ & $66.5 \pm 5.7$ & $53.2 \pm 6$ & $43 \pm 9$ & $105 \pm 15.3$ \\
\hline
\end{tabular}

${ }^{1} P<0.001$ between control and malnourished groups for body weight, $\mathrm{PCV}, \mathrm{Hb}$, iron, transferrin, and $\mathrm{C} 3$ and $P<0.01$ for serum albumin .
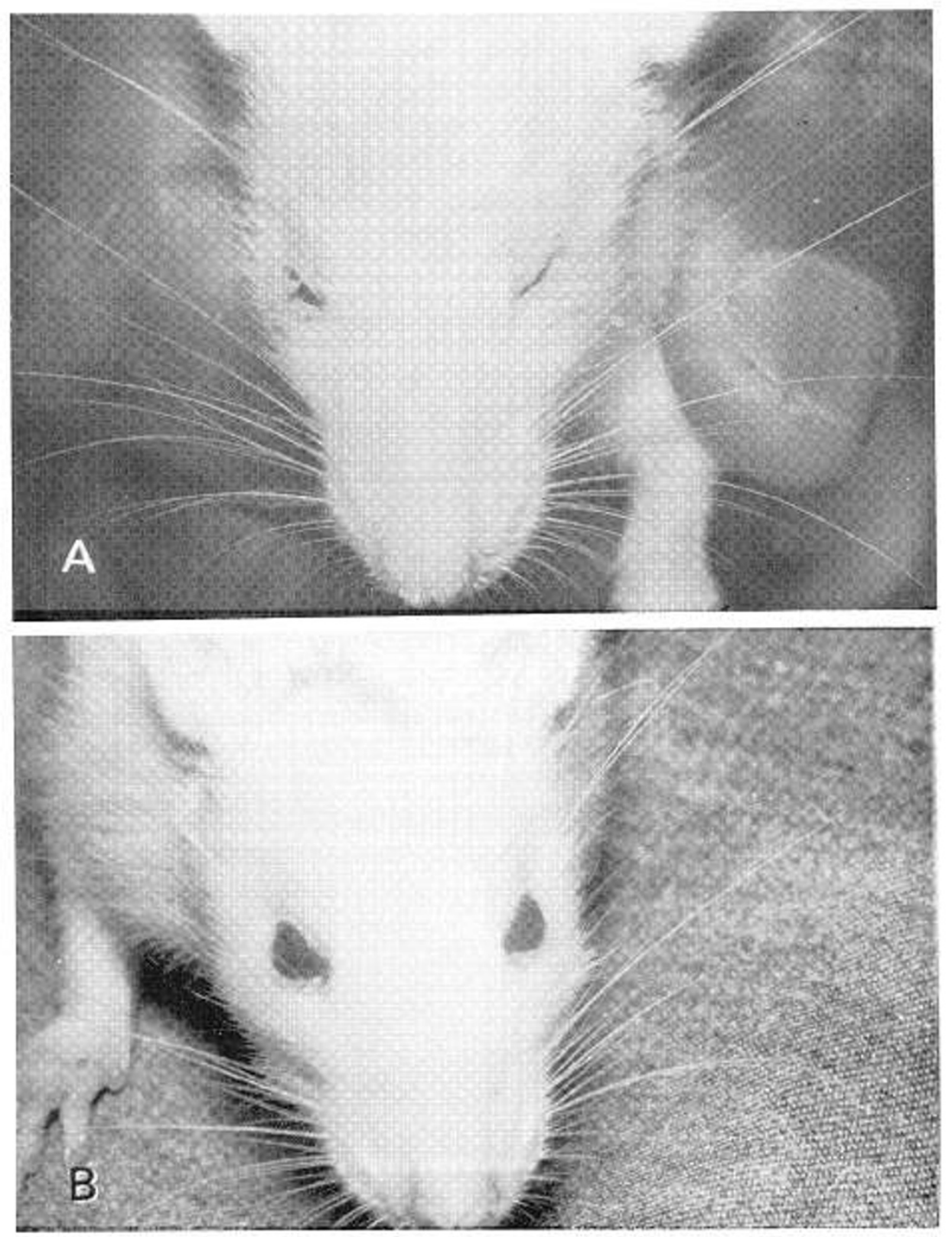

Fig. 1. A: appearance of a rat given oral iron supplement during refeeding. Note the bilateral conjuctivitis developed by this animal. $B$ : appearance of a rat that had no iron supplement during refeeding. Note the absence of conjuctivitis.

\section{CONCENTRATIONS OF SERUM PROTEINS (TABLE 4)}

C3 and transferrin concentrations were significantly lower $(P$ $<0.01)$ in malnourished rats that had $195 \mathrm{mg}$ and $260 \mathrm{mg}$ iron than in those that were not given any oral iron. It was also observed that the lower the serum transferrin, the more severe was the infection and that the more severe the infection, the greater was the reduction in $\mathrm{C} 3$ levels.

\section{SERUM IRON}

Table 4 shows that the serum iron levels increased as the dose of iron given increased and that the severity of infection was 
directly proportional to the serum iron level. An inverse relationship between serum transferrin and iron was noted.

\section{BACTERIOLOGIC DATA}

Eye swabs obtained from all the malnourished rats that were given oral iron during refeeding yielded some growth on culture. The number and types of organisms isolated increased with the dose of iron. Thus, more organisms were isolated from swabs obtained from rats on $195 \mathrm{mg}$ than from those on $65 \mathrm{mg}$. Very few organism were isolated from the eye swabs of animals that were not given any iron. The most significant qualitative observation was that swabs from rats on iron supplement yielded a profuse growth of a Moraxella sp. (Fig. $2 A$ ). This organism was very scanty in swabs obtained from rats that had no iron (Fig. $2 B$ ). Table 5 gives a summary of the bacteriologic data.

\section{DISCUSSION}

The results of this study showed that oral iron supplementation during refeeding of experimentally malnourished rats resulted in various types of infection, the severity of which depended on the dose of iron given. Furthermore, a high protein diet without added iron was observed to cause marked clinical, hematologic, and biochemical improvements in the malnourished animals, suggesting that an adequate supply of protein is the most important factor in the treatment of malnutrition. Although we were not able to estimate the transferrin saturation in rats, our results suggest strongly that there is a close association between high serum iron, low serum transferrin, and increased bacterial infection since malnourished rats that were given even small doses of iron during refeeding had higher serum iron levels, lower serum transferrin, and higher incidence of bacterial infections than malnourished rats that were not given any iron supplement.

Schade and Caroline (10) identified conalbumin, a constituent of egg-white, as an iron-binding protein and observed its ability to inhibit the growth of bacteria. Later (11), these authors identified siderophilin (transferrin) in human blood. Subsequently, other iron-binding proteins in other body fluids were identified. Thus, Masson and Heremans (6) identified lactoferrin in milk and later in tears, saliva, and bile. In vitro studies have revealed that all of these iron-binding proteins inhibit the growth of bacteria because of their high binding association constant for iron such that there is no iron available for irondependent microorganisms. Jackson and Burrows (4) showed that the injection of iron enhances the growth of bacteria in mice, and Rogers (9) observed that in lethal infections in guinea pigs, bacteria grew extremely rapidly in animals treated with iron. In protein-calorie malnutrition, McFarlane et al. (7) showed that the serum transferrin concentration was very closely related to prognosis and that when the transferrin concentration was less than $0.40 \mathrm{mg} / \mathrm{ml}$ the prognosis was grave. It is therefore likely that the observed increase in incidence of infection in malnourished rats that were given oral iron supplement during refeeding was due to a combination of high serum iron and low serum transferrin.

The interrelationship between complement, transferrin, and iron has not been fully investigated. Griffiths (3) suggested that in the case of highly virulent Pasteurella septica, transferrin can act together with antibody and complement to interfere with bacterial RNA synthesis, and that this action can be reversed by iron compounds. Thus, in situations of low serum transferrin, low $\mathrm{C} 3$, and high serum iron, bacterial replication is enhanced. It would appear that malnutrition which causes a marked decrease of both transferrin and C3 concentrations plays a synergistic role with increasing serum iron concentration in predisposing to bacterial infection.

Most of the organisms isolated from malnourished rats on iron supplement were likely to be commensals which became virulent as a result of increased rate of replication in the presence of high 

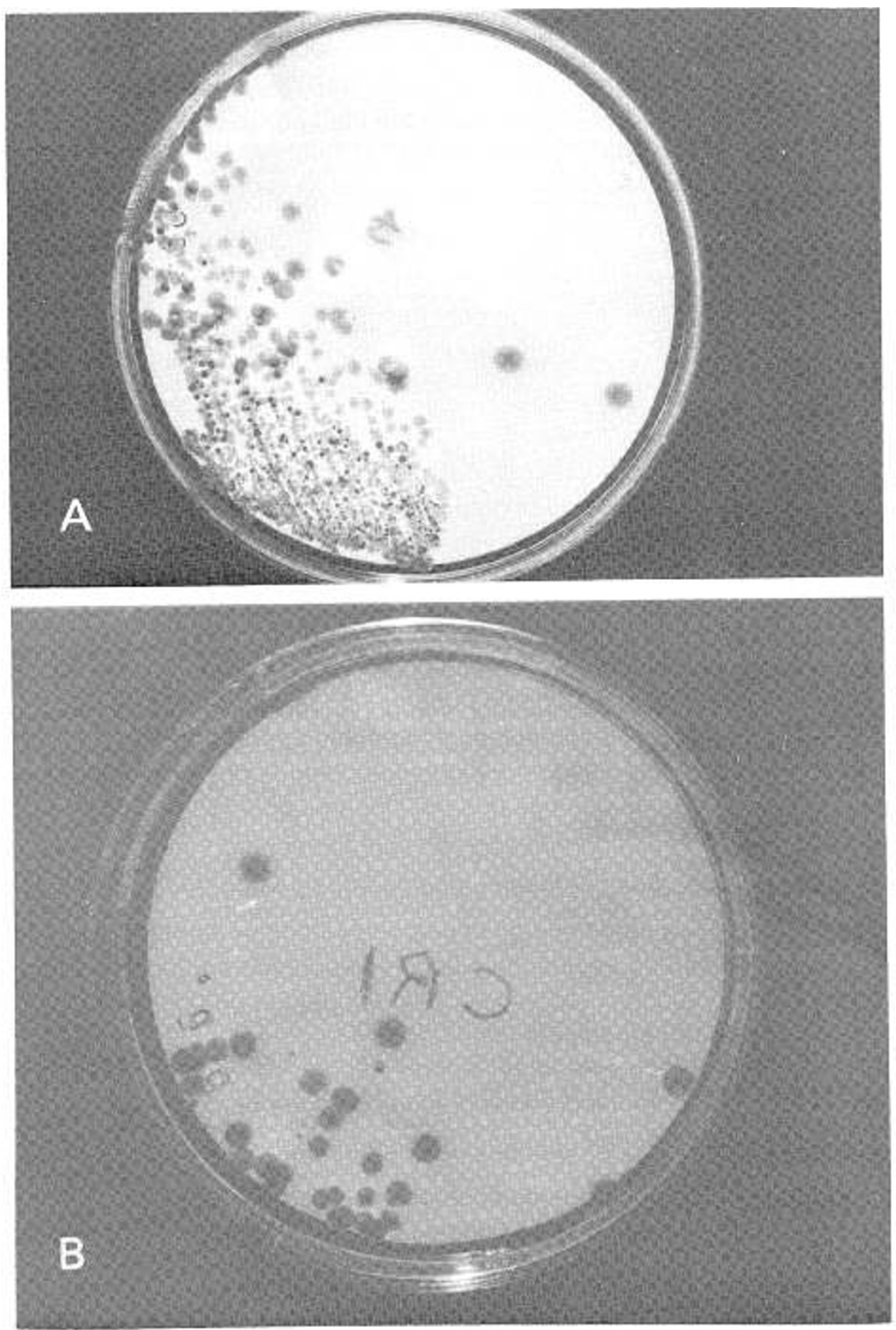

Fig. 2. A: plate showing the profuse growth of a Moraxella sp. from the eye swab of a rat that was given oral iron supplement during refeeding. $B$ : plate showing the scanty growth of a Moraxelia sp. from the eye swab of a rat that had no oral iron supplement during refeeding.

Table 5. Organisms isolated from the eyeswabs of different groups of rats after refeeding for 30 days ${ }^{1}$

\begin{tabular}{|c|c|c|c|c|c|c|c|c|c|}
\hline \multirow[b]{2}{*}{ Animal group } & \multirow[b]{2}{*}{$\begin{array}{c}\text { Dose of iron given, } \\
\mathrm{mg} / \mathrm{kg} / \text { day }\end{array}$} & \multirow[b]{2}{*}{ E. coli } & \multicolumn{7}{|c|}{ Types of organisms isolated } \\
\hline & & & $\begin{array}{c}\text { Alcaligenes } \\
\text { sp. }\end{array}$ & S. aureus & S. faecalis & $\begin{array}{l}\text { S. haemolyti- } \\
\text { cus }\end{array}$ & $\begin{array}{l}\text { Corynebac- } \\
\text { teria }\end{array}$ & Moraxella & Clostridia \\
\hline I & 65 & + & + & + & + & + & + & - & - \\
\hline II & 130 & \pm & ++ & ++ & ++ & ++ & ++ & + & + \\
\hline III & 195 & +++ & ++ & +++ & ++ & ++ & + & +++ & ++ \\
\hline IV & 260 & +++ & +++ & ++ & +++ & +++ & ++ & +++ & ++ \\
\hline $\mathrm{V}$ & Nil & \pm & \pm & \pm & - & - & - & - & - \\
\hline Well fed controls & 260 & \pm & \pm & \pm & - & - & - & - & - \\
\hline
\end{tabular}

${ }^{1}$ The results in each group are the average scores obtained from five animals.

2 Plates were scored as follows: \pm : a few colonies, present only in inoculum well; + : colonies present in first streak; ++ : colonies present in second streak; +++ : colonies present in third streak; - : no organisms isolated. 
serum iron and low serum transferrin. Moraxella infection was common only in those rats that had iron, suggesting that this organism is highly iron dependent.

In conclusion, this study suggests that a high iron supplement during the treatment of children with protein-calorie malnutrition may predispose to increased bacterial infection, especially if the serum transferrin concentration is very low.

\section{CONCLUSION}

Protein-energy malnutrition causes iron deficiency anemia in Sprague-Dawley rats. The inclusion of iron supplement in the diet during the refeeding of these animals caused various types of infection, the severity of which was directly proportional to the dose of iron given. A high protein diet alone produced the same effects on PCV and hemoglobin values as a high protein diet containing $65 \mathrm{mg}$ iron/ $\mathrm{kg}$ body $\mathrm{wt} / \mathrm{day}$, although this latter diet caused infection in the malnourished rats. The severity of bacterial infection was found to be related to the serum concentrations of iron and transferrin.

Isolation of the organisms responsible for the infections showed the presence of Escherichia coli, Streptococcus faecalis, Staphylococcus aureus, Streptococcus haemolyticus, and a Moraxella species.

\section{REFERENCES AND NOTES}

1. Cowan, S. T., and Steel, K. J.: Manual for the Identification of Medical Bacteria, Ed. 2 (Cambridge University Press, Cambridge, England).

2. Ganote, C. E., and Nahara, G.: Acute ferrous sulphate hepatotoxicity in rats:
An electron microscopic and biochemical studies. Lab. Invest., 28: 426 (1973).

3. Griffiths, E.: Mechanism of action of specific antiserum on Pasteurella septica: Selective inhibition of net macromolecular synthesis and its reversal by iron compounds. Eur. J. Biochem., 23: 69 (1971).

4. Jackson, S., and Burrows, T. W.: The virulence-enhancing effect of iron on non-pigmented mutants of virulent strains of Pasteurella pestis. Brit. J. Exp. Pathol., 37: 577 (1956).

5. Mancini, G., Carbonara, A. O., and Heremans, J. F.: Immunochemical quantitation of antigens by single radial immunodiffusion. Immunochemistry, $2: 235$ (1965).

6. Masson, P. L., and Heremans, J. F.: Studies on lactoferrin, the iron-binding protein of secretions. Protides Biol. Fluids Proc. Colloq. Bruges, 14: 115 (1966).

7. McFarlane, H., Reddy, S., Adcock, K. J., Adeshina, H., Cooke, A. R., and Akene, J.: Immunity, transferrin and survival in kwashiorkor. Brit. Med. J., IV: 268 (1970)

8. Ojeda, F. G.: Anemias nutricionales (Nutritional anemias). Rev. Med. Cordoba, 60: 230 (1972)

9. Rogers, H. J.: Bacteriostatic effects of horse sera and serum fractions on Clostridium welchii; $\mathrm{A}$, and the abolition of bacteriostasis by iron salts. Immunology, 12: 285 (1967)

10. Schade, A. L., and Caroline, L.: Raw hen egg white and the role of iron in growth inhibition of Shigella dysenteriae, Staphylococcus aureus, Escherichia coli and Saccharomyces cerevisiae. Science, 100: 14 (1944).

11. Schade, A. L., and Caroline, L.: An iron-binding component in human blood plasma. Science, 104: 340 (1946).

12. Segura, A. S., Maristany, G., Armelini, M. E. G. De, Medina, L. R. De, Ryser, O. R., Sagliono, I., Airasca, M., and Bepre, E. P. De: Anemia ferropenica en la desnutricion del lactante. (Iron deficiency anemia in malnutrition in infants.) Rev. Colombiana Pediat. Puericult., 5: 341 (1972)

13. Requests for reprints should be addressed to: S. O. Olusi, M.D., Faculty of Health Sciences, University of Ife, Ile-Ife Nigeria (West Africa).

14. Received for publication January 27,1977

15. Accepted for publication August 24, 1977. 